\title{
Effect, Appearance
}

National Cancer Institute

\section{Source}

National Cancer Institute. Effect, Appearance. NCI Thesaurus. Code C71600.

An outward appearance. 